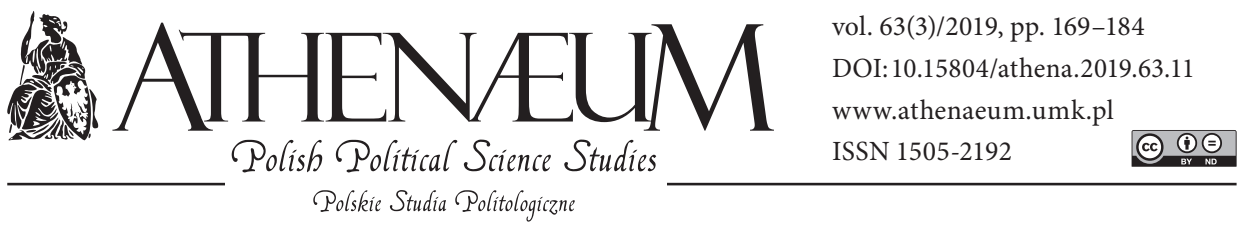

\title{
THE STATE OF SOCIAL INVESTMENT AS A DERIVATION OF THE WELFARE STATE
}

\author{
PAŃSTWO INWESTYCJI SPOŁECZNYCH \\ JAKO DERYWACJA PAŃSTWA DOBROBYTU
}

Agnieszka Makarewicz-Marcinkiewicz* $\odot$

\begin{abstract}
According to Anthony Giddens, the state of social investment was to be the third way between neoliberalism and the post-war welfare state, the quintessence of a future-oriented approach in which the state becomes an entrepreneur. In this concept, state expenditures are perceived as a form of investment in human capital and understood as positive prosperity. The implementation of the state of social investment entails the phenomenon of citizenship of responsible risk recipients. In the literature on social investments, the reflection is repeated that this model is the result of the need to respond to the radically changed economic and social order, including the challenges of a globalized knowledge-based economy. The model encourages active participation in the search for solutions for social structural changes, such as aging population, changing the family model or the labour market. Despite the fact that the social investment model is based on the free market perceived as the most suitable for the organisation of societies, this
\end{abstract}

Według Anthony’ego Giddensa państwo inwestycji społecznych miało być trzecią drogą między neoliberalizmem a powojennym państwem opiekuńczym, kwintesencją podejścia zorientowanego na przyszłość, w którym państwo staje się przedsiębiorcą. Wydatki państwa są w tej koncepcji postrzegane jako forma inwestycji w kapitał ludzki i rozumiane jako dobrobyt pozytywny. Implementacja państwa inwestycji społecznych pociąga za sobą zjawisko obywatelstwa odpowiedzialnych odbiorców ryzyka. W literaturze dotyczącej inwestycji społecznych powtarza się refleksja, że model ten jest wynikiem potrzeby reagowania na radykalnie zmieniony porządek gospodarczy i społeczny, $\mathrm{w}$ tym wyzwania zglobalizowanej gospodarki opartej na wiedzy. Model zachęca do aktywnego uczestnictwa w poszukiwaniu rozwiązań dla społecznych zmian strukturalnych, takich jak: starzenie się społeczeństwa, zmiana modelu rodziny czy rynku pracy. Pomimo faktu, że model inwestycji społecznych oparty jest na

* University of Wrocław, Faculty of Social Sciences. 
is no longer the so-called inexorable market. It emphasizes the need for government intervention and targeting market forces to improve both economic and social performance. The aim of the article is to verify the thesis about the investment paradigm of social policy between free-market mechanisms and the welfare state, two extremely different interpretations of contemporary socioeconomic reality.

Keywords: state of social investment; investment social policy; welfare state; social justice; social inclusion wolnym rynku, postrzeganym jako najbardziej odpowiedni dla organizacji społeczeństw, to nie jest to już tak zwany nieubłagany rynek. Podkreśla się bowiem potrzebę interwencji rządu i ukierunkowania sił rynkowych w celu poprawy zarówno wyników gospodarczych, jak i społecznych. Celem artykułu jest weryfikacja tezy o usytuowaniu paradygmatu inwestycyjnej polityki społecznej pomiędzy mechanizmami wolnorynkowymi a państwem dobrobytu, dwiema skrajnie różnymi interpretacjami współczesnej rzeczywistości społeczno-gospodarczej.

Słowa kluczowe: państwo inwestycji społecznych; inwestycyjna polityka społeczna; państwo dobrobytu; sprawiedliwość społeczna; inkluzja społeczna

\section{INTRODUCTION}

Social investments are defined as a set of policies and ideas that emerged in the mid $1990^{\mathrm{s}}$ as a reaction to profound and fundamental changes in the labour market and the demographic structure of societies, as well as the emergence of new threats and social needs (Hemerijck, 2013).

The concept of the state of social investment appeared in debates on the reform of the welfare state in the late 1990s (Esping-Andersen, 2002; Jenson \& Saint-Martin, 2003). Supporters of this kind of reforms claim that they want to change the orientation of social policy from strictly compensatory to a preventive one, implementation of which should primarily focus on the investment in the potential of people. The centre of such preventive strategies are activation policies (Bonoli, 2011). The expected return on investment is an increase in the share of population in the labour market and higher productivity of its participants.

The Social Investment Package proposed by the European Commission in 2013 provides guidance to Member States on more efficient and effective social policy in response to the major currently facing challenges: high level of financial hardship, rising poverty and social exclusion, as well as record unemployment, especially among young people, and the aging of societies (European Commission, 2013). 
Under the influence of the social investment model, there has been a change in the perception of the role of social policy, which in the new paradigm should not focus on passive protection of people from the threat of the free market through financial transfers and benefits, but prepare and equip them with tools that allow for maximal integration with the market (Jenson \& Saint-Martin, 2003).

The aim of this article is to analyse the investment paradigm in the context of the welfare state's assumptions and traditions. The assumed hypothesis refers critically to the added value of the social investment regime in social policy. The state of social investment is just another hybrid of the expanding economic liberalism and welfare state, invented to justify the cuts in public spending. The new kind of redistribution governed by free market laws.

The fundamental research question to be asked is whether the idea and the so far achievements of welfare state are compatible with the new investment approach and whether we are dealing with a welfare state model adapted to reality or with a completely new, definitely liberal quality?

Helpful in achieving the research goal, verifying of the hypothesis and answering the research questions will be the usage of: descriptive method, which can be characterised as an attempt to determine, describe or identify processes and phenomena (Ethridge, 2004, p. 24); secondary analysis of research, defined as "the re-analysis of either qualitative or quantitative data already collected in a previous study, by a different researcher wishing to address a new research question" (Payne \& Payne, 2004); and comparative studies, which are perceived as fundamental tool of analysis that "sharpens the power of description and plays a central role in concept-formation by bringing into focus suggestive similarities and contrasts among cases" (Collier, 1993, p. 105).

\section{THE STATE OF SOCIAL INVESTMENT: A LITERATURE REVIEW}

In the last decade, social investments have been recognized as a strategy not only promoting equal opportunities, but also social integration by preparing people to function in the changing labour markets. The social investment strategy corresponds to the key dimensions indicated by the President of the Commission, José Manuel Barroso, when in 2005 he defined the vision of the European social model in terms of equal opportunities and social inclusion. The difference between Barroso's vision and the concept of social investment consisted only in 
the fact that Barroso defined his version of the European social model in the context of the assumed goals without focusing on specific policy instruments, while the investment approach mainly oscillates around such instruments.

The EU 2020 strategy differs from the Barroso's European Social Model, since it combines political and instrumental elements. Skills and other elements of human capital development are regarded today as a component of inclusive growth and are to be compatible not only with intelligent growth, but also with sustainable (green) growth. This dimension of social investment paradigm was highlighted in June 2010. It became clear then that unilateral focus on expenditure control is not consistent with the investment agenda that should be based on real expenditure (investments) in the short and medium term. This approach to social investment focuses on the supply side, coherent with neoliberalism, and on the trust in state intervention in combination with Keynesianism (Palme \& Cronert, 2015, p. 5). Just after the conceptual clump one can tell that we are dealing with a developmental hybrid, which is impossible to implement. This means that some elements will be omitted in the implementation process.

According to Anthony Giddens, it is a mistake to separate the economic dimension of the European Union from its social dimension. Much of what is happening in the social policy system is important for economic efficiency. This applies, for example, to education or public health. The author coined the term "state of social investment" to describe the reality in which the social welfare system can and should survive in the version of the state of social investment. Giddens explained the new approach on the example of a health care system that should be activated not only when people are already ill, but a lot earlier, through investments in health prevention and preventing inequities in health. This vision of development is different from the current model of welfare state, however in Giddens' opinion, the only way to defend and maintain the European Social Model. The author postulates the introduction of investments in human capital wherever it is possible, instead of directly providing services aimed at economic sustainability. At the same time, Giddens claims he cannot imagine a state without effective aid institutions (Giddens, 2013).

In the new paradigm, the government spending on services such as health, education, social security and the like should not be seen as expenditure on consumption or as part of redistribution. These should be conceptualized and justified as investments that will bring a return in the form of a larger share in the labour market, greater employee productivity, higher personal income and greater economic growth. At this point, the deliberations on whether the state 
of social investment is still a welfare state, only that using other instruments or experiencing the next phase of the progressive liberalization of the state, could be finished. If only the issue of stimulating economic growth is raised, it is certainly a neoliberal discourse.

The concept of the welfare state, in Giddens' opinion, usually suggests something reactive, which protects the citizen when things go wrong. A modern welfare state, or a modern state of social investment should be more based on assets that people have, regardless of whether it is an education or other form of quality. According to the author, the old welfare state was reactive, trying to overcome gigantic evils, as specified by William Beveridge: misery, ignorance, desire, idleness, and disease. Giddens points to the need for a model that he calls positive welfare, not just a reactive social welfare system. He proposes to introduce an investment system that develops people's capabilities. Instead of talking negatively about the evil we have to face, we need to pay attention to the values that can be created. Therefore, as he claims, one should not focus on inactivity, unemployment, but on positive aspects such as: happiness, complacency, self-esteem. Changing the way of thinking is to help create a positive model of the state of social investment based on assets, because the state provides infrastructure for an effective market economy. Describing the paradigm of social investments, Giddens also searches for a conceptual reconstruction of the welfare state (Giddens, 2004, p. 3).

The state of social investment is a holistic development paradigm that involves political changes in three interrelated dimensions: the transition from old to new social risks, from cash benefits to social services and from ex-post remedies to preventing - ex-ante (De Deken, 2014, p. 262). The investment approach can also be seen as one of many attempts to justify social policy as a productive factor, not simply draining the economy. This idea also finds application in the concept of varieties of capitalism. The expected return on investment is the increase in the share of population in the labour market and higher productivity of participants in this market (Hall \& Soskice, 2001).

Social investment is also perceived as an alternative to neo-liberal retorts focusing on retrenchment in social spending, and what is more, as a key element in responding to the macroeconomic situation in Europe (Morel, Palier, \& Palme, 2011; Hemerijck, 2013; Diamond \& Lodge, 2014).

Social investments are also to contribute to deepening integration within EU and creating a vision for social Europe. Since social investment framework can be used to stimulate welfare reforms, dealing with the aftershocks of the financial 
crisis and improve Member States' resilience to social risks (Wilson, 2014; Ostner \& Stolberg, 2015). In this approach, it is claimed that an instrument used to quasi-market redistribution of generated wealth can itself cause an integration of European social orders. The initial level of development, and so the possibilities of the instrument's efficient usage, has not been taken into consideration.

Functional perspective concentrates on social investment as fiscal and legal regulations, political and cultural determinants for activities stimulating social changes and solving major social problems. Such an attitude is known as modernisation of social policy from distributive and based on consumption towards oriented on the improvement of the position on labour market (Peeters \& de Tavernier, 2015; Haberkern, Schmid, \& Szydlik, 2015).

A social investment, like any investment, should be designed and implemented with a view to profit. It is expected that the social benefits will be expressed in monetary terms in order to show financial investment returns. Hence the need to create measures that take into account social values. The most widespread are:

- SIMPLE (Social IMPact Measurement for Local Economic) - a general organisational management model aimed at analysing social effects;

- Social Accounting and Audit - monitoring of non-profit organisations activities;

- GRI (Global Reporting Initiative Guidelines) - institution supporting organisations in estimating their social value.

The most common method is the Social Return on Investments (SROI), which was established in the 1990s in the United States. In Europe, the British Economists from the New Economic Foundation (www.neweconomics.org) became interested in the idea of calculating SROI. The European Social Return on Investment Network - ESRoIN - has also been established as an informal group whose members come from the Netherlands, Belgium, Germany, Scotland and England, working on creating new standards in managing the organisation.

SROI allows for reporting different types of values created by an organisation (economic, social, environmental). The main task of this gauge is to identify and measure social value while using monetary values. The SROI calculation method is based on the reporting methods used in financial accounting, mainly in the profit and loss accounts. The SROI calculation is based on the economic value (enterprise value) and socio-economic value, i.e., the social effects that can be quantified (Social Purpose Value). The combination of these two values gives a mixed value (Gair, 2009). This gauge has got evaluative and prognostic dimension. The evaluation is based on the analysis of the observed effects of the 
organization's activity, while the prognosis allows to indicate the estimated return on investment in the perspective of several years.

In the process of social value analysis, the most difficult is the identification and monetization of effects, and in the prognostic dimension of SROI, the additional difficulty is to discount the future value to the current period and identify the risk of achieving the expected results. In the context of social cost-benefit analysis, some inputs are difficult to estimate using the market price system, since such prices do not exist or do not express marginal benefits and social costs (Stiglitz, 2004). The thread of this measurement method, in the context of the consequences resulting from its application, will be continued in the next section.

\section{SOCIAL INVESTMENT AS A FOUNDATION OF THE THIRD WAY. THE WELFARE STATE'S PRIVATISATION}

The state of social investment was to be the third way between neoliberalism and the post-war welfare state, the quintessence of a future-oriented approach in which the state becomes an entrepreneur (Giddens, 1998). However, even among supporters of the privatization of the welfare state, seeing in this process the chance of survival of the paradigm, there are different approaches towards the scope of privatisation. Anthony Giddens and Gøsta Esping-Andersen differ in their understanding of what constitutes productive and unproductive social spending, the perception of the role that they attach to social policy and how to strike a balance between the rights and obligations of citizens. Giddens emphasizes the moral risks and unproductive nature of unemployment benefits and similar programs, whereas Esping-Andersen recognizes their productive values, for example, in the context of mitigating the cyclical fluctuations in employment. Giddens appreciates the incentives created by inequality, while Esping-Andersen points to problems generated by inequality (Morel et al., 2011).

The state of social investment concept is not the first widely discussed, introduced into development strategies, and implemented derivation of the welfare state. It was preceded, for example, by the concept of active labour market policy (ALMP). However, ALMP was limited to specific programs of the labour market. It was not an overall development strategy and that was why it was possible to fully unite the citizens with the market.

Giuliano Bonoli identifies various types of active labour market policy that has been implemented in Europe since the $1950^{\circ}$ from the perspective of social 
investment. He argues that active labour market policy is too broad category to be used without further specification and develops the typology of four different types of active labour market policies focusing on: strengthening motivation, employment and occupation assistance, and investing in human capital. Changes in the approach to ALMP result from the general economic and labour market context (Bonoli, 2011).

Emma Dowling sees in the social investment paradigm the continuation and implementation of the David Cameron Big Society concept from 2009. The discourse of the Big Society aimed to mobilize the affective ability of citizens to empathize and care for their fellow brothers, and thus to take on the responsibility for health care, care for children and care for the elderly, to run local libraries, deal with unemployment, to fight poverty and inequality. Such mobilization was to contribute to an increase of general well-being in the context of further limiting and privatizing the welfare state. By encoding these affective skills, seen as restoring civic virtues, the state could withdraw from the management, financing and provision of public services, relying on volunteering and local communities (Dowling \& Harvie, 2014, p. 4).

Capital provided by social investors (in anticipation of profit) is to enable social enterprises (responding to social needs), to function, while a competitive environment in which such social investments and social enterprises appear, is to ensure innovation and efficiency in the delivery of public services. From the perspective of the state, the political economy of the Big Society promised to solve three crises: the capitalist crisis of accumulation, the crisis of social reproduction, and the state's financial crisis (Dowling \& Harvie, 2014, pp. 2-3).

The crisis of capital accumulation, described as: "the crisis of capital reproduction and the relationship between capital and global work, which characterizes the neoliberal period" (McNally, 2009, pp. 40-44), is mainly caused by the loss of national control over flows of transnational capital, where and how the funds generated in one country are reinvested elsewhere or take the form of speculation.

The crisis of social reproduction refers to the whole of interwoven processes, within which self-reproduction of the socio-economic system takes place and through which people living in this system (individuals, communities, generations) reproduce themselves, their cultures and social relations (Dowling \& Harvie, 2014, p. 8).

In the context of the financial crisis of the state and the political reaction to this state of affairs in the form of savings and deep cuts in public spending, 
there was a clear political appeal to attract private investors to provide capital to finance projects that used to be financed with public funds. This action is an attempt to transfer risk to the private sector. In this context, the concept of ethical investments emerged. As in the case of Corporate Social Responsibility (CSR), this type of activity is voluntary, the private sector is still not obliged, but only encouraged to take responsibility for social development. To a large extent, the financing of social investments is the provision of loans that will increase borrowers' financial capacities, but also change their behaviour and teach social risk management (Nicholls, 2010).

Research conducted by Dowling show that social investments are not a progressive counterbalance to predatory neoliberal capitalism. The paradigm is rather a part of an ongoing neoliberal project. Social investments are aimed at generating and then using profits to create wealth. In addition, the pursuit of social investments consists in subordinating these activities to objective, usually economic, measures. The author argues that social investment paradigm is the new limit of capitalist accumulation (Dowling \& Harvie, 2014).

These studies also refer to the consequences of using the most popular method of measuring profit from social investments - Social Return on Investments (SROI). Thanks to the social value method, governments hope to estimate the broader benefits of the service in a situation when these benefits cannot easily be quantified in standard monetary categories, e.g., a local library to stimulate creative and cognitive opportunities for young and old people, or a community centre offering workshops on saving water or isolating homes. The value of such ventures is difficult to estimate: their effects or impact are not comparable to the performance of washing machines or cars, which can be relatively easily collected and counted. The problem is that without a measure no value can be determined, and therefore the sense of determining social value is to develop indicators that can quantify the units of social return from investment in financial terms. Social enterprises and social organisations have got the social motive at the centre of their actions, and not the profit. For this reason, the government declares that it wants to provide these organisations with better access to the procurement process and an advantage over the company's service providers. While the corporation has a tendency to perceive its social obligations in terms of keeping the balance between the negative externalities of environmental pollution or social inequalities, a social enterprise, that not only provides but also measures social return on investment, provides the government with exactly what it expects - the cost efficiency (Dowling \& Harvie, 2014, pp. 12-13). 
Whereas the estimation of cost effectiveness does not cause major difficulties, regardless of the measurement method used, the calculation of the profit rate remains a problem. The state of social investments puts multi-sectoral social policy entities in front of dilemmas that did not arise in a traditional welfare state.

\section{INVESTMENT OR REDISTRIBUTION?}

It has been suggested that the consumption of social services provided in accordance with the paradigm of social investments is usually related to work and earnings. These services therefore have a less redistributive profile than traditional money transfers, which can lead to the effect of St. Matthew - increasing economic and social inequalities in countries oriented towards social investments (Cantillon, 2011).

The emergence of this phenomenon is all the more likely that, as argued, although at the aggregate level, with effective policy, the efficiency of social investments in the labour market would be theoretically possible, the results indicate that the percentage of people living in the European Union in households without employment, practically did not decrease, despite the increase in general employment rates. This fact raised doubts as to the complementarity of the objectives: to increase employment and reduce poverty underlying the social investment paradigm (Corluy \& Vandenbroucke, 2014).

What is more, the example of the Futurebuilders organisation proves that social investment of even easily available public money can be inefficient. Futurebuilders was an initiative of the Labour Government founded in 2004 to promote and implement loan financing for the third sector in Great Britain. Futurebuilders is an organisation perceived as one of the largest government interventions in the field of social investments. The program was closed for new applicants in 2010. Eight years seems to be a long enough period in modern public policy, especially in a field such as social investments. It is worth noting that the payments from the Futurebuilders fund were slower than expected, the most investments were made in 2008-2010. This state of affairs is a reflection of many factors, including the time that has passed since the opening of orders for the third sector, especially at the local level, the availability of other funds, but also the reluctance to take loans by third sector organisations. Of the 171,000 third sector organisations operating at that time in the United Kingdom, loans were granted to 215 organisations. In total, 745 organisations 
have prepared business plans for financing, and more than 2,000 organisations have been inquiring about the possibility of financing. The greatest difficulties were the implementation of often complicated investments, which required a significant growth of the organisation, which could not be met by small subsidies. Although the social investor, Futurebuilders, correctly identified the problem and provided the appropriate tool, the initiative was not successful (Wells, 2012).

In the investment approach, citizens are expected to assume full responsibility for their well-being. As a consequence, governments implement political tools to shape the responsibilities. Citizens are directed to the correct behaviour by the stick and carrot method. The incentives offered are, e.g., remuneration for work, while the penalty may be the limit of entitlements to social benefits for taking up a job (Gilbert \& Van Voorhis, 2001).

Building a development paradigm on individual responsibility has been confronted with criticism due to the fact that it is not a good basis for establishing a just social policy. In this context, particular attention is paid to the process of implementing disciplinary policies guided by the concept of individual responsibility, without the possibility of taking into account the circumstances of making the choices, which entails the risk of deepening existing inequalities. The exemplification of disciplinary policy are the restrictions in the provision of assistance to parents of children who are in a difficult financial situation. Parents lose the financial support (toll relief) when the child has got unjustified absences at school. The support from the state in return for the sole responsibility of the child completely abolishes the responsibility of the school (Cantillon \& Van Lancker, 2012).

The rhetoric of the individual's responsibility is part of a popular neo-liberal discourse, in which people are responsible for their own (unsuccessful) decisions, as well as the consequences of their own actions or choices. Such a narrow vision of responsibility denies the context of these decisions, the circumstances of the action, which often boils down to an unequal distribution of choices that determine the choices. In this context, it is recognized that disciplinary policies dependent on responsible behaviour reinforce existing inequalities. Firstly, attention is paid to the need to maintain a balance between rights and obligations on the labour market. Secondly, caution is recommended when implementing policies based on a narrow concept of individual responsibility. This involves the danger of blaming the victim and strengthening existing inequalities and behavioural patterns. Although modern societies - according to neoliberal 
propaganda - are liberated from social classes and transformed into places where everyone has the opportunity of forging one's own destiny, studies show that well-being and opportunities are as much defined by origin as it used to be a half century ago (Erikson \& Goldthorpe, 1992).

Although many supporters of an active welfare state demand both social investments and stronger incentives to encourage people to work, in fact governments supporting the so-called new social welfare agreement seem to focus more on deregulation of the labour market, reducing employment protection, limiting access to social insurance and relying more on solutions that bring measurable, easy to demonstrate benefits than pursuing policies to increase human capital and facilitate labour mobility (Taylor-Gooby, 2004).

The Swedish prototype of the investment approach looked different. In Sweden, the beginnings of the social investment program date back to the 1930s, and its implementation was an antidote to the effects of the Great Depression and what was later referred to as the population crisis (decreasing birth rates). During these crises, Alva and Gunnar Myrdal developed an approach to social policy aimed at easing production and reproduction, which opened up to an investment perspective in the field of social policy. The Myrdals were in favour of a policy that would combine direct economic support for families with children with indirect housing support, as well as opportunities for women's participation in the labour market. The issue of population concerned not only the quantity, but above all the quality of the population in terms of social conditions for human capital creation. The fight against poverty consisted in increasing the productivity and employment of the population, and the countercyclical policy boiled down to combating poverty and inequality. Redistribution was perceived in this model as a kind of irrigation system (Korpi, 1985).

The main objective of the Swedish model was equality, not just poverty reduction. Equality in the category of social classes and gender equality. The model, which was finally appreciated for the victorious fight against poverty, was controversial in the post-war period. Doubts were related to the direction of policies to combat inequality and not directly poverty. The fight against inequalities was part of a wider strategy to create an open society with high mobility and liquidity. The model retains the idea of full employment. Moreover, full employment should be perceived as the basic assumption of the model and the strategy to prevent poverty. In particular, social insurance related to earnings is recommended as an effective instrument for reducing poverty or even eradicating poverty (Palme \& Cronert, 2015, pp. 7-8). 
Nonetheless, in the investment social policy, there is no question of combating inequalities, on the contrary, it assumes the competition of human resources on the free market (Palme \& Cronert, 2015, p. 10). Since the question of social inequality is not treated as a priority in this model, there are still significant gender inequalities in developed democracies, even though many of them have experienced an increase in the employment rate of women. Such inequalities include: the gender gap in unpaid care and domestic work, segregation in the labour market, feminized part-time work, the pay gap between women and men, and the "glass ceiling effect" experienced by women (Morel et al., 2011).

The persistence of these inequalities makes scientists adopt an attitude of limited expectations in relation to this phenomenon. There is a lack of faith in the possibilities of social investment policy in the context of mitigating gender inequality. Effective handling of these issues would require the implementation of new programs, such as paid parental leave, available and compulsory for both women and men, equal rights to work part-time and full-time, or other measures that allow or encourage men to take on more household responsibilities. There are various ideas for implementation of programs aimed at gender equality. Socalled dual model of a paid carer occurs in different versions, while the most often implemented ones still impair women in the labour market, such as parttime women work combined with unequal distribution of unpaid care work in private sphere of life. In this case, the social investment approach seems to be useful in explaining the individual and social losses of the untapped potential of women.

\section{CONCLUSION}

The paradigm of social investments emphasizes the importance of individual investments in human capital, which are to enable people to take care of themselves in a liberalized labour market and in the conditions of a reduced social policy regime that transfers the responsibility for well-being to the citizens.

The social investment perspective will not guarantee social progress, which includes everyone, unless it is complemented by a strong commitment to traditional forms of social protection. Social investment assumes competing for funds and not everyone is winning out of this competition. That is why an investment cannot be the only form of intervention if the organisation of societies in the form of a welfare state is to be continued. 
The redistributive and compensatory nature of the welfare state has caused that Sweden has got the best results in fighting inequality and poverty, with which the state of social investment is still struggling. Proponents of social investment paradigm emphasize that the welfare state has dealt with problems thanks to exorbitant expenditures and it is difficult to disagree with this argument, but it should be also taken into consideration that welfare state regime is based on the assumption that the government (and not the individual, corporation or local community) is responsible for well-being of its citizens, ensuring a minimum standard of living. This commitment, however, must be associated with the provision of expensive social services.

The aim of the article was not to evaluate these two, in the author's opinion, contradictory, developmental paradigms. Therefore, the issue of the superiority of the state's social investment regime in the post-industrial reality over the imposing regime of the welfare state straight from the industrial era has not found its resolution here. However, the argumentation quoted above enables to make a statement that the state of social investments is not a welfare state (unless we adopt the Esping-Andersen typology and recognize welfare state in every contemporary socio-economic regime that is based on democracy). In terms of both, the analysis and implementation, the state of social investment is an unsuccessful derivation (if not deviation) of the welfare state.

\section{REFERENCES:}

Bonoli, G. (2011). Active Labour Market Policy and Social Investment: A Changing Relationship. In: N. Morel, B. Palier, \& J. Palme (eds.). Towards a Social Investment Welfare State? Ideas, Policies and Challenges (pp. 181-204). Bristol: Policy Press. DOI: 10.1332/policypress/9781847429247.003.0007.

Cantillon, B. (2011). The Paradox of the Social Investment State: Growth, Employment and Poverty in the Lisbon Era. Journal of European Social Policy, 21(5), 432-449. DOI: $10.1177 / 0958928711418856$.

Cantillon, B., \& Van Lancker, W. (2012). Solidarity and Reciprocity in the Social Investment State: What Can be Learned from the Case of Flemish School Allowances and Truancy? Journal of Social Policy, 41(4), 657-675. DOI: 10.1017/ S0047279412000359.

Collier, D. (1993). The Comparative Method. In: A.W. Finifter (ed.). Political Science: The State of the Discipline II (pp. 105-119). Washington D.C.: American Political Science Association.

Corluy, V., \& Vandenbroucke, F. (2014). Individual Employment, Household Employment, and Risk of Poverty in the European Union: A Decomposition Analysis. In: 
B. Cantillon, \& F. Vandenbroucke (eds.). Reconciling Work and Poverty Reduction: How Successful Are European Welfare States? (pp. 94-130). Oxford: Oxford University Press.

De Deken, J. (2014). Identifying the Skeleton of the Social Investment State: Defining and Measuring Patterns of Social Policy Change on the Basis of Expenditure Data. In: B. Cantillon, \& F. Vandenbroucke (eds.). Reconciling Work and Poverty Reduction: How Successful Are European Welfare States? (pp. 260-285). Oxford: Oxford University Press.

Diamond, P., \& Lodge, G. (2014). Dynamic Social Security after the Crisis: Towards a New Welfare State? International Social Security Review, 67(3-4), 37-58. DOI: 10.1111/issr.12047.

Dowling, E., \& Harvie, D. (2014). Harnessing the Social: State, Crisis and (Big) Society. Sociology, 48(5), 869-885. DOI: 10.1177/0038038514539060. Retrieved from (and cited after): https://lra.le.ac.uk/bitstream/2381/29294/2/Dowling\%20and\%20 Harvie\%20Harnessing\%20the\%20Social\%20\%5BSociology\%202014\%5D.pdf (pp. $1-26)$.

Erikson, R., \& Goldthorpe, J.H. (1992). The Constant Flux: A Study of Class Mobility in Industrial Societies. Oxford: Clarendon Press.

Esping-Andersen, G. (ed.) (2002). Why We Need a New Welfare State. Oxford: Oxford University Press.

Ethridge, D.E. (2004). Research Methodology in Applied Economics. Hoboken, NJ: WileyBlackwell.

European Commission (2013). Social Investment: Commission Urges Member States to Focus on Growth and Social Cohesion. Retrieved from: https://ec.europa.eu/social/ main.jsp?catId=89\&furtherNews=yes\&newsId=1807\&langId=en.

Gair, C. (2009). SROI Act II: A Call to Action for Next Generation SROI. REDF. Retrieved from: https://ccednet-rcdec.ca/files/ccednet/pdfs/2009-REDF_SROI_Act2.pdf.

Giddens, A. (2004). The Welfare State in a Modern European Society. Retrieved from: http://www.uoc.edu/symposia/caixamanresa/jornadaeconomia/eng/giddens.pdf.

Giddens, A. (2013). Five minutes with Anthony Giddens: "The European Social Model Can and Must Survive the Crisis". LSE. Retrieved from: http://blogs.lse.ac.uk/ europpblog/2013/11/04/five-minutes-with-anthony-giddens-the-european-socialmodel-can-and-must-survive-the-crisis/\#Author.

Gilbert, N., \& Van Voorhis, R. (2001). Activating the Unemployed: A Comparative Appraisal of Work-Oriented Policies. New Brunswick \& London: Transaction Publishers.

Haberkern, K., Schmid, T., \& Szydlik, M. (2015). Gender Differences in Intergenerational Care in European Welfare States. Ageing and Society, 35(2), pp. 298-320. DOI: $10.1017 /$ S0144686X13000639.

Hall, P.A., \& Soskice, D. (2001). Varieties of Capitalism. The Institutional Foundations of Comparative Advantage. Oxford: Oxford University Press.

Hemerijck, A. (2013). The Reform Capacities of European Welfare States. In: B. Cantillon, \& F. Vandenbroucke (eds.). For Better, For Worse, For Richer, For 
Poorer: Labour Market Participation, Social Redistribution and Income Poverty in the EU (pp. 238-259). Oxford: Oxford University Press. DOI: 10.1093/acprof: oso/9780199926589.003.0008.

Jenson, J., \& Saint-Martin, D. (2003). New Routes to Social Cohesion? Citizenship and the Social Investment State. Canadian Journal of Sociology, 28(1), 77-99. DOI: $10.2307 / 3341876$.

Korpi, W. (1985). Power Resources Approach vs. Action and Conflict: On Causal and Intentional Explanations in the Study of Power. Sociological Theory, 3(2), 31-45.

McNally, D. (2009). From Financial Crisis to World-Slump: Accumulation, Financialisation, and the Global Slowdown. Historical Materialism, 17(2), 35-83. DOI: $10.1163 / 156920609 X 436117$.

Morel, N., Palier, B., \& Palme, J. (2011). Beyond the Welfare State as We Know It? In: N. Morel, B. Palier, \& J. Palme (eds.). Towards a Social Investment Welfare State? Ideas, Policies and Challenges (pp. 1-30). Bristol: Policy Press.

Nicholls, A. (2010). The Institutionalization of Social Investment: The Interplay of Investment Logics and Investor Rationalities. Journal of Social Entrepreneurship, 1(1), 70-100. DOI: 10.1080/19420671003701257.

Ostner, I., \& Stolberg, C. (2015). Investing in Children, Monitoring Parents: Parenting Support in the Changing German Welfare State. Social Policy and Society, 14(4), 621-632. DOI: 10.1017/S1474746415000287.

Palme, J., \& Cronert, A. (2015). Trends in the Swedish Social Investment Welfare State: 'The Enlightened Path' or 'The Third Way' for 'the Lions'? Poverty Reduction in Europe: Social Policy and Innovation, Discussion Paper 15/12.

Payne, G., \& Payne, J. (2004). Key Concepts in Social Research. London: Sage.

Peeters, H., \& de Tavernier, W. (2015). Life Courses, Pensions and Poverty among Elderly Women in Belgium: Interactions between Family History, Work History and Pension Regulations. Ageing and Society, 35(6), 1171-1199. DOI: 10.1017/ S0144686X14000129.

Stiglitz, J.E. (2004). Ekonomia sektora publicznego. Warszawa: Wydawnictwo Naukowe PWN. Taylor-Gooby, P. (ed.) (2004). New Risks, New Welfare: The Transformation of the European Welfare State. Oxford: Oxford University Press.

Wells, P. (2012). Understanding Social Investment Policy: Evidence from the Evaluation of Futurebuilders in England. Voluntary Sector Review, 3(2), 157-177. DOI: $10.1332 / 204080512$ X649342.

Wilson, K.E. (2014). New Investment Approaches for Addressing Social and Economic Challenges. OECD Science, Technology and Industry Policy Papers, 15, 1-41. DOI: $10.1787 / 23074957$. 